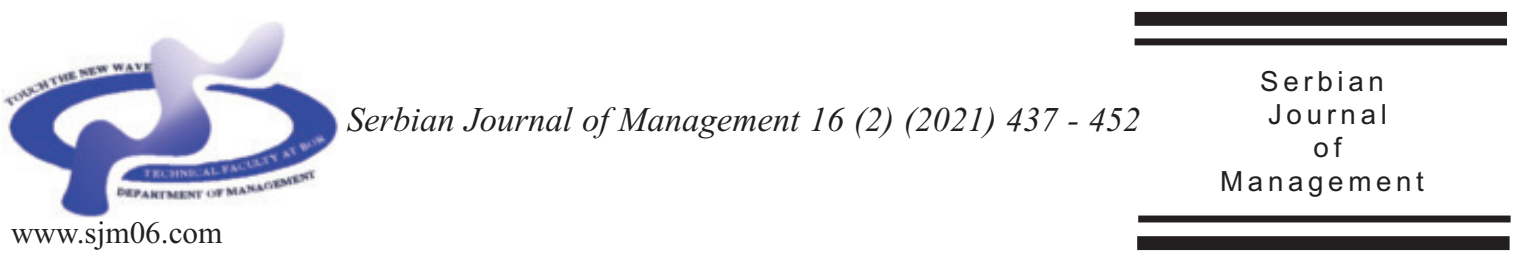

\title{
PERCEPTION OF SELECTED STRATEGIC MANAGEMENT FACTORS OF SME IN V4 COUNTRIES
}

\author{
Jaroslav Belása , Milan Damborskýa ${ }^{\mathbf{a}}$ Zdenko Metzkera ${ }^{\mathbf{a}}$ and Petr Šuleřb \\ ${ }^{a}$ Tomas Bata University in Zlin, Faculty of Management and Economics, \\ Mostni 5139, 76001 Zlin, Czech Republic

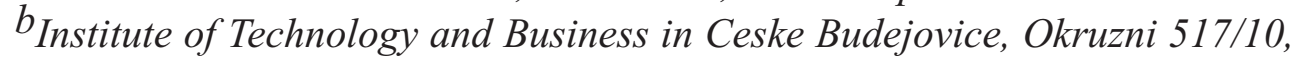 \\ 37001 Ceske Budejovice, Czech Republic
}

(Received 23 July 2021; accepted 27 September 2021)

\begin{abstract}
The objective of the paper was to present current theoretical findings in the area of strategic management of small and medium-sized enterprises (SMEs) in the Visegrad Four (V4) countries. Within the stated objective, the weight of individual strategic management factors was quantified and trends in the Czech Republic were compared with other V4 countries. Empirical research was conducted between October 2019 and March 2020 in V4 countries by means of an online questionnaire. The overall number of accepted questionnaires was as follows: Czech Republic (CR): 454, Slovak Republic (SR): 368, Poland (PL): 364, and Hungary (HU): 399. Questionnaires were completed by company owners and top managers. The empirical research provided several interesting findings. On the one hand, SMEs confirmed that strategic management is an important part of corporate management; on the other hand, strategic management is not implemented in the everyday life of SMEs and is not implemented through action plans and programmes. The level of agreement with the statement that quality strategic management improves the competitiveness of enterprises and their stability in domestic and foreign markets was not very high. Not surprisingly, SMEs have significant weaknesses in monitoring and personal risk management. The research results point to the need for increasing the level of strategic risk management in the segment of SMEs, which is an important factor in improving their competitiveness in a globalizing economic environment.
\end{abstract}

Keywords: small and medium-sized enterprises, strategic management, strategic management factors, the Visegrad Four countries

\footnotetext{
*Corresponding author: metzker@utb.cz
}

DOI: 10.5937/sjm16-33274 


\section{INTRODUCTION}

Strategic management is one of the fastest developing areas of social sciences. It represents an interdisciplinary field integrating economics, sociology, and system and organization theory. A specific area of strategic management is its implementation in small and medium-sized enterprises, which have a specific position compared to large enterprises. Although SMEs represent a considerable share in economic activity, many studies are focused on large enterprises only. SMEs have unique characteristics that allow them to take a special position in the economic system. In comparison with large enterprises, small and medium-sized enterprises have limited access to capital (see e.g. Czerwonka \& Jaworki, 2021) but are more flexible in decision making (see e.g. Ferreira de Araújo Lima et al., 2020; or Fiala \& Hedija, 2015; Hashi \& Krasniqi, 2011; or Belas et al., 2020; Srovnalíková et al., 2020).

Strategic management in small and medium-sized enterprises is not of smaller importance than in large enterprises. Competitive markets require flexibility of SMEs.

Knowledge of strategic management processes and active management of strategic risks enables companies to prepare and react to any critical changes in a timely manner. The process of strategic management changes depending on the size of company but also on managers and top management. The patterns of business strategy have been changing in recent years, with formal strategy becoming dominant. This is probably related to the significantly reduced duration of business strategy (Gavurova et al., 2020a). Small and mediumsized enterprises are an important element in the economic ecosystem. Supporting them appears to be very important in the context of economic development (Hanggraeni et al., 2019).

Based on the above, it can be stated that the perception of strategic management is crucial for a comprehensive understanding of SME behaviour. This fact motivated the authors to this research focused on the perception of selected factors of strategic management in small and medium-sized enterprises.

The paper is divided into 5 basic chapters. The introductory part is followed by the Theoretical part, which deals with the current approaches in the issue of strategic management in small and medium-sized enterprises in Central Europe with emphasis on the V4 and neighbouring countries. The following chapter presents the objective, methodology, and data used for the research. The findings are then confronted with previous research and the results are presented in the discussion part. The basic findings are then summarized in the conclusion chapter.

\section{THEORETICAL PART}

Every company has its own definition of strategy or strategic management. Nevertheless, strategic management (Abbass \& Alkhafaji, 2003) is a process of evaluating corporations and their environment in order to achieve long-term objectives of the organization and the related adaptation to the environment, including risk mitigation (Ivanova et al., 2019). Keřkovský \& Vykypěl (2006) state that strategic management is based on long-term predictions and helps solve business problems and look for future opportunities. Szczepańska-Woszczyna 
(2018) adds that strategic management is a tool using which managers can make their decisions for the future. Proper and organized application of strategic management may help companies improve their competitiveness and achieve better results than using non-formal business management (Carreras et al., 2018).

Sedláčková \& Buchta (2006) see the advantages of strategic management in giving organizations goals and direction for their positive future development. According to Tichá \& Hron (2005), the basic function of strategic management is the generation of competitive advantages, which are the most important condition of a successful business. The full strategic potential of a company should be focused on achieving this goal by means of day-to-day operational decisions based on long-term strategic focus. Strategic management is a challenge for the whole company in each moment of its existence, not only for a limited number of experts once a year. It is a way of thinking, a guide to actions, and a determining factor in the behaviour of each company member.

Analoui \& Karami (2003) state that strategic management facilitates understanding the current situation of a company, and besides analysis, it identifies strategically important activities and goals. Short et al., (2007) consider performance analysis to be a key part of research on strategic management. Strategic planning and networking have the potential to enhance the growth of small and medium-sized enterprises (Tkacova et al., 2017; Hansen \& Hamilton, 2011). Fonseca et al. (2018) claim that strategic management consists of formulating a strategy, its implementation, and evaluation in terms of achieving longterm predefined corporate goals. In this context, other authors mention also external and internal analysis, which aims to understand threats and opportunities in the environment, formulating strategies, their implementation by means of plans and policies, evaluation, and control (Pisar \& Bilkova, 2019).

However, even a good strategy may fail if its implementation is not proper and controlled. Many authors believe that the implementation of a strategy is an even more critical moment than its formulation (e.g. Andrews et al., 2017). In this context, corporate social responsibility as a part of business strategy plays an important role (Metzker \& Zvarikova, 2021; Metzker \& Streimikis, 2020).

People who create and implement strategic management should have the right knowledge and skills to tackle challenges in the area of sustainable development. According to Frantz et al. (2017), strategic management depends on owners, managers, and leaders, who think, analyse, and implement long-term goals, set direction, and create well-defined plans to address the main challenges and problems concerning the development and growth of organizations. Identification of strategies is the responsibility of strategic managers. Unlike large companies, in SMEs, strategic managers can be also their owners (Fuertes et al., 2020).

Companies that implement strategic management achieve financial stability and sustainability (Saltaji, 2013). Therefore, the authors of this paper believe that strategic management in companies should be an inseparable part of company management, as it shows its importance for modern business management.

The perception of the importance of strategic planning in SMEs is conditioned by the environment in which the company is. 
This is confirmed by empirical studies conducted in different geographical areas (Kocisova et al., 2018). Clifton et al. (2020) conducted research in a group of $121 \mathrm{SME}$ companies in South East Wales. The authors asked various questions related to strategic planning in the following areas: (a) Business objectives, (b) Company growth, (c) Skills and training, (d) Innovation, (e) Networking, (f) Business prospects and drivers of growth. South-East Wales is one of the lagging regions of Great Britain. The case study confirmed that strategic planning is not implemented adequately. Competition and day-to-day solving of problematic situations impede small enterprises from carrying out the most efficient types of strategic planning and creating networks for growth and innovations. Poor or improper implementation of these activities highlights the need for targeted management training.

Wiesner \& Millett (2012) focused their attention on the issue of the nature and prevalence of strategic practices in Australian SMEs and their differences based on company size. The research included 1230 Australian small and medium-sized enterprises. The results of the research showed a systematic approach to strategic planning and adherence to formal rules. However, the process of generating strategies in organizations participating in the research is not only systematic and targeted. The results show various shades of grey, since SMEs tend to avoid other lesserknown sophisticated tools. Therefore, despite the fact that Australian SMEs are able to implement targeted strategic management, they do not make full use of the wide range of tools available for generating strategies.

O'Regan \& Ghobadian (2002) state that little attention has been paid to the process of generating SME strategies or the effectiveness of strategic planning in the sector of small and medium-sized enterprises. Planning is often inefficient due to the implementation problems, which are often related to the inability of SMEs to identify and overcome potential barriers to strategic planning.

The generation of strategies is related also with the preparatory activities of responsible managers or their activities when setting and adhering to strategic goals. Tell (2012) deals with the issue of behaviour of top managers in small and fast-growing manufacturing companies. According to the author, managers in these companies engage in many different activities; however, there are activities that take most of their time. These activities include primarily operational activities (e.g. activities related to production, marketing, and sale) and/or administrative (e.g. activities related to personnel management and financial matters). From the perspective of strategic management, managers spend very little time carrying out strategic activities. Most managers use "a simplistic strategy"; this can be due to the fact that for such managers, it is difficult to change their initially successful operational and administrative activities in order to enhance the development of their companies (Bacik et al., 2020). In a way, such managers are "stuck" in a pathdependency mindset, although the growth of their companies requires them to adopt a more flexible management strategy.

Strategic management is mostly implemented in large companies. However, it is gradually being implemented also in small and medium-sized enterprises (Kudej et al., 2021). Wang et al. (2007) focused on the question of why SMEs do not implement strategic planning. The authors state that the 
levels of strategic planning are higher in SMEs whose owners/managers are growthoriented, while in SMEs whose owners/managers pursue non-economic (personal) motives. It shall be noted that many SME owners and managers do not strive for growth and are content to remain small.

The issue of SME management is addressed also in the context of specific conditions of Central Europe. The strategic management of SMEs in terms of innovations is dealt with by Bodlaj \& Čater (2019). They claim that management reacts to a changing environment and behaviour of competitors. In the example of Slovenia, the authors confirm the results of previous general studies (Rosenbusch et al., 2011; Lee et al., 2014).

SME management in the area of human resources is addressed by Łobos et al. (2020). A case study of 764 small and medium-sized enterprises from the $\mathrm{CR}$ and Poland confirm the importance of HR management, when attracting talented people to the company, appropriate rewarding, ensuring that employees know exactly their tasks, decision-making and responsibility, running a small and mediumsized enterprise appropriately, supporting cooperation among employees, and creating positive working atmosphere are crucial tasks. This is possible only if good strategic planning is implemented, since, as the authors state, managers and leaders need to set goals and adopt measures to achieve them.

The issue of strategic management is comprehensively dealt with by e.g. Švárová \& Vrchota (2013). According to the authors, the strategic management of a small company is determined by its specifics, which include limited access to capital, limited resources to employ experts in the field, and primary solution of operational activities. The research conducted shows that small and medium-sized enterprises with better strategic management achieve better financial results. The research included 176 SMEs.

Talent management is dealt with by Egerová et al. (2015). Empirical research was conducted on a group of 174 companies in the Czech Republic and Slovakia. The authors found out that talent management is not the primary concern of most organizations in the Czech Republic and Slovakia. This is not surprising, since, for most organizations, especially SMEs, talent management is not a key concern. However, the authors believe that talent management is a major challenge for all organizations which aim to strengthen competitive advantages. The strategic approach of small and mediumsized enterprises to talent management is limited, with most companies applying an ad hoc approach to talent management practice.

Rolínek et al. (2014) analyse process management in SMEs. For the purposes of evaluating the implementation of process management, the authors developed a combined indicator of implementation of process management principles. The authors concluded that the process management principles are applied in most medium-sized enterprises; they are not applied in microenterprises.

Kot et al. (2018) deal with the implementation of customer-supplier chain management, which is an important component of corporate management and a very important part of (long-term) management from the perspective of the sustainability of customer-supplier relationships. The authors used a research sample of small and medium-sized 
enterprises from Poland and Romania. The results show similar involvement in the implementation, although there are significant differences in selected areas, such as cost reduction and focus on end customers.

Quality strategy and process management are interconnected with business processes. Okręglicka et al. (2015) analysed the maturity of business processes in SMEs in Poland and tried to identify the areas which require the intensification of process management. The authors consider business process management as one of the success factors, which should be integrated into the corporate development concept. The paper presents the results of empirical research conducted in 2015 on a sample of 138 companies in Poland.

Kulej-Dudek (2013) analysed knowledge management in SMEs in Čenstochová using the Model of Stages in Employee Knowledge Growth as an evaluation tool developed by the author. The degree to which the company efficiently uses knowledge management using the processes of localization, acquisition, collection, development, sharing, distribution, and storage of knowledge is an indicator of the business maturity in this field. Measuring the maturity of solutions in knowledge management represents a reference point for improving its state. To make knowledge acquired by an employee fully available, it is necessary to create a specific environment, company culture, and practices that would mobilise and motivate knowledge sharing in all stages of business management.

Kolarov \& Georgieva (2020) analysed the management of SMEs. Their research findings confirmed the importance of building managerial teams with the participation of managers, international activities specialists for the success of internationalization and company growth; however, the question of involving family members in business management remains unanswered.

Karácsony \& Czibula (2020) deal with the relationship between the company performance and leadership style in Hungarian SMEs. Their findings are based on the analysis of 637 companies. The results show that leadership style has a significant impact on corporate performance in the companies under review. The research has shown that company performance is better if managers adopt an autocratic leadership style.

Labudová \& Jánošová (2019) and Gavurova et al. (2020b) aim to identify the major obstacles to the development of small and medium-sized enterprises and determine similar and different features in state support for entrepreneurship in the Czech Republic and Slovakia. In this context, the authors state that the main identified obstacles include mainly administrative and time complexity of establishing a company, administrative burden for entrepreneurs, instability of legislative environment, confusion and non-transparency of laws, weak law enforcement, long judicial review, high tax and payment burden, complicated tax payment, excessively long time to obtain a building permit, insufficient innovation potential and technological preparedness of SMEs, limited access to financing, inconsistent context of supporting SMEs, and continuing clientelism and corrupt practices. 


\section{AIM, METHODOLOGY AND DATA}

The objective of the paper is to present current theoretical knowledge in the area of strategic management in the SME sector of V4 countries. Within the objective set, the weights of selected factors of strategic management will be quantified and the trends in the Czech Republic will be compared with other V4 countries.

Empirical research in strategic management of SMEs was conducted between October 2019 and March 2020 in V4 countries by means of an online questionnaire. The total number of accepted questionnaires was as follows: 454 in the Czech Republic (CR), 368 in the Slovak Republic (SR), 364 in Poland (PL), and 399 in Hungary (HU).

The questionnaires were completed by company owners and top managers. The average rate of return of the questionnaires was $3.6 \%$ in the CR, $5.5 \%$ in the SR, $4.7 \%$ in $\mathrm{PL}$, and $4.6 \%$ in $\mathrm{HU}$.

The structure of respondents in the $\mathrm{CR}$ was as follows: company size: microenterprises (up to 9 employees) $63.9 \%$, small enterprises (10-49 employees) 23.6\%, medium-sized enterprises $\quad(50-249$ employees) $12.5 \%$; business sector: services $29.3 \%$, trade $20.1 \%$, production $17.4 \%$, construction $13.9 \%$, tourism $2.4 \%$, agriculture $2.4 \%$, transport $2.2 \%$, other sectors $12.3 \%$.

The Slovak Republic: micro-enterprises $58.7 \%$, small enterprises $28.8 \%$, and medium-sized enterprises $12.5 \%$. Business sectors: services $30.1 \%$, trade $20.7 \%$, manufacturing $19.0 \%$, construction $11.1 \%$, tourism $4.1 \%$, agriculture $2.2 \%$, transport $2.7 \%$, and other sectors $10.1 \%$.

Poland: micro-enterprises $55.5 \%$, small enterprises $23.4 \%$, and medium-sized enterprises $21.1 \%$. Business sectors: services $51.4 \%$, trade $12.6 \%$, manufacturing $14.8 \%$, construction $6.1 \%$, tourism $1.1 \%$, agriculture $0.8 \%$, transport $4.4 \%$, and other sectors $8.8 \%$.

Hungary: micro-enterprises $67.3 \%$, small enterprises $18.3 \%$, and medium-sized enterprises $19.4 \%$. The structure of SMEs by business sector was as follows: services $32.3 \%$, trade $11.3 \%$, production $16.5 \%$, construction $7.3 \%$, tourism $3.5 \%$, agriculture $18.8 \%$, transport $4.0 \%$, other sectors $6.3 \%$.

In the paper, the following statements will be examined:

ST1: Strategic management in a company is an integral part of corporate governance.

ST2: Strategic management is implemented in the everyday life of our company and realised through action plans and programs.

ST3: Quality strategic management improves the competitive ability of our company and its stability in domestic and foreign markets.

ST4: Our company regularly monitors, evaluates, and manages strategic risks.

The respondents could choose from five options: Strongly agree, Agree, Neither agree or disagree, Disagree, Strongly disagree.

Based on the expert judgement method, the following statistical hypotheses were formulated:

H1: Strategic management is an important part of company management. More than 50 $\%$ of the respondents in all V4 countries agree with this statement.

H1a: There are statistically significant differences between the $\mathrm{CR}$ and other V4 countries in the overall structure of responses and in positive attitudes of entrepreneurs concerning ST1.

$\mathrm{H} 2$ : Strategic management is 
implemented in the everyday life of the company. More than $50 \%$ of the respondents in all V4 countries agree with this statement.

$\mathrm{H} 2 \mathrm{a}$ : There are statistically significant differences between the $\mathrm{CR}$ and other V4 countries in the overall structure of responses and in positive attitudes of entrepreneurs concerning ST2.

H3: Quality strategic management improves the competitiveness of the company. More than $50 \%$ of the respondents in all V4 countries agree with this statement.

H3a: There are statistically significant differences between the $\mathrm{CR}$ and other V4 countries in the overall structure of responses and in positive attitudes of entrepreneurs concerning ST3.

H4: Our company regularly monitors, evaluates, and manages strategic risks. More than $50 \%$ of the respondents in all V4 countries agree with this statement.

H4a: There are statistically significant differences between the CR and other V4 countries in the overall structure of responses and in positive attitudes of entrepreneurs concerning ST4.

To evaluate the defined scientific hypotheses, the method of descriptive statistics (percentage), the Chi-square test, and the Z-score method were used. Statistically significant differences were compared through Pearson statistics at the significance level of $5 \%$. The calculations were made through free software available online.

\section{EXPERIMENTAL RESULTS}

The tables below present the results of comparing the attitudes of the respondents in the area of strategic risk.

The level of agreement with STR1 ranges between $64 \%$ and $83 \%$. The highest level of agreement was provided by Czech entrepreneurs; Slovak managers agreed least with the importance of strategic managers. The overall analysis of Czech entrepreneurs showed differences in their attitudes compared to Polish and Hungarian entrepreneurs. In contrast, the structure of responses of Czech and Slovak entrepreneurs was similar. The values of the $\mathrm{Z}$-score confirmed the existence of statistically significant differences in positive attitudes of SMEs between Czech and Polish

Table 1. Comparison of STR1

\begin{tabular}{|c|c|c|c|c|c|}
\hline $\begin{array}{l}\text { STR1: Strategic management is } \\
\text { an important part of company } \\
\text { management. }\end{array}$ & $\begin{array}{c}\text { Czech } \\
\text { Republic } \\
\text { (CR) } 454\end{array}$ & $\begin{array}{l}\text { Slovak } \\
\text { Republic } \\
\text { (SR) } \\
368\end{array}$ & $\begin{array}{c}\text { Poland (PL) } \\
364\end{array}$ & $\begin{array}{l}\text { Hungary } \\
\text { (HU) } \\
399\end{array}$ & $\begin{array}{c}\text { Z-score/ } \\
\text { p-value } \\
\text { CR/SR } \\
\text { CR/PL } \\
\text { CR/HU }\end{array}$ \\
\hline 1. Strongly agree & 185 & 119 & 101 & 166 & $1.1591 / 0.2404$ \\
\hline 2. Agree & 192 & 175 & 132 & 164 & $\begin{array}{c}6.2111 / \\
p<0.0001\end{array}$ \\
\hline $1+2$ together $\%$, number & $83.04 / 377$ & $79.89 / 294$ & $64.01 / 233$ & $82,71 / 330$ & $0.1288 / 0.8966$ \\
\hline 3. Neither agree or disagree & 64 & 63 & 90 & 40 & \\
\hline 4. Disagree & 8 & 7 & 28 & 22 & \\
\hline 5. Strongly disagree & 5 & 4 & 13 & 7 & \\
\hline $\begin{array}{l}\text { Chi-square: } \\
\text { p-value }\end{array}$ & $\begin{array}{c}\text { CR/SR } \\
6.3743 / \\
0.1729 \\
\end{array}$ & $\begin{array}{c}\text { CR/PL } \\
45.4872 / \\
\text { p<0.0001 } \\
\end{array}$ & $\begin{array}{c}\text { CR/HU } \\
12.14 / \\
0.0163 \\
\end{array}$ & & \\
\hline
\end{tabular}


entrepreneurs. Czech entrepreneurs agree with STR1 significantly more than entrepreneurs from Poland.

Based on the calculations performed, H1a is accepted - there are statistically significant differences, but only between the Czech Republic and Hungary with Poland. Hypothesis H1 is also accepted, since more than $50 \%$ of the respondents agreed with STR1.

Within all countries under review, Hungarian entrepreneurs agree most with the statement that strategic management is implemented by means of action plans in the everyday life of the company. Using the Chisquare test, it was found that the overall structure of Czech entrepreneurs' respondents does not differ from the attitudes of other entrepreneurs. The values of Z-score confirm the existence of statistically significant differences in positive attitudes of SMEs between Czech and Hungarian entrepreneurs.

Hypothesis $\mathrm{H} 2$ is accepted, because in all cases, more than $50 \%$ of the respondents agreed with the statement.

Hypothesis $\mathrm{H} 2 \mathrm{a}$ is rejected, since there are no statistically significant differences in the overall structure of responses between the countries under review.

In Hungary, the level of agreement with the statement concerning improving competitiveness through the implementation of strategic management is the highest of all V4 countries (up to 73\%); in Poland, it is the lowest. The overall structure of the responses was comparable. The Z-score test values confirmed the existence of statistically significant differences in the positive attitudes of SMEs between Czech and Hungarian entrepreneurs ( $p$-value $=0.0155)$. Czech entrepreneurs significantly less agree with STR3 than Hungarian entrepreneurs.

Hypothesis $\mathrm{H} 3$ is accepted since there were more than $50 \%$ of positive answers in all countries.

Based on the total responses, we can state that no significant differences were recorded between the countries; $\mathrm{H} 3 \mathrm{a}$ is thus rejected.

Strategic risks are most monitored and managed in Hungary and least in Poland. Based on the results of the Chi-square test, it was found that the overall structure of the Czech entrepreneurs' respondents differs from the responses of Slovak and Hungarian entrepreneurs. In contrast, the structure of

Table 2. Comparison of STR2

\begin{tabular}{|c|c|c|c|c|c|}
\hline $\begin{array}{l}\text { STR2: Strategic management } \\
\text { is implemented in the } \\
\text { everyday life of our company } \\
\text { and realised through action } \\
\text { plans and programs }\end{array}$ & $\begin{array}{c}\text { Czech } \\
\text { Republic } \\
(\mathrm{CR}) \quad 454\end{array}$ & $\begin{array}{c}\text { Slovak } \\
\text { Republic } \\
\text { (SR) } \\
368\end{array}$ & $\begin{array}{c}\text { Poland (PL) } \\
364\end{array}$ & $\begin{array}{c}\text { Hungary } \\
\text { (HU) } \\
399\end{array}$ & $\begin{array}{l}\text { Z-score/ } \\
\text { p-value } \\
\text { CR/SR } \\
\text { CR/PL } \\
\text { CR/HU }\end{array}$ \\
\hline 1. Strongly agree & 80 & 58 & 67 & 67 & $\begin{array}{c}-1.5515 / \\
0.1211\end{array}$ \\
\hline 2. Agree & 147 & 146 & 133 & 162 & $\begin{array}{c}-1.4071 / \\
0.1585\end{array}$ \\
\hline $1+2$ together $\%$, number & $50.00 / 227$ & $55.44 / 204$ & $54.94 / 200$ & $57.39 / 229$ & $-2.16 / 0.0308$ \\
\hline 3. Neither agree or disagree & 153 & 119 & 106 & 121 & \\
\hline 4. Disagree & 49 & 37 & 39 & 36 & \\
\hline 5. Strongly disagree & 25 & 8 & 19 & 13 & \\
\hline $\begin{array}{l}\text { Chi-square: } \\
\text { p-value }\end{array}$ & $\begin{array}{c}\text { CR/SR } \\
9.2968 / \\
0.0541 \\
\end{array}$ & $\begin{array}{c}\mathbf{C R} / \mathbf{P L} \\
2.4608 / \\
0.6517 \\
\end{array}$ & $\begin{array}{l}\text { CR/HU } \\
7.8792 / \\
0.0961 \\
\end{array}$ & & \\
\hline
\end{tabular}


the responses of Slovak and Czech entrepreneurs is similar.

$\mathrm{H} 4 \mathrm{a}$ is thus accepted since the existence of statistically significant differences in the attitudes of company owners/managers has been confirmed.

On the other hand, hypothesis $\mathrm{H} 4$ is rejected, since more than $50 \%$ of positive answers were obtained only from Slovak or Hungarian SMEs.

\section{DISCUSSION}

The paper indicates that strategic management in the SME sector in the region of Central Europe, or more specifically, the sub-region of V4 countries, has not still been paid adequate attention to. The results show that strategic planning is not fully integrated in the decision-making system in most

Table 3. Comparison of STR3

\begin{tabular}{|c|c|c|c|c|c|}
\hline $\begin{array}{l}\text { STR3: Quality strategic } \\
\text { management improves the } \\
\text { competitive ability of our } \\
\text { company and its stability in } \\
\text { domestic and foreign markets }\end{array}$ & $\begin{array}{c}\text { Czech } \\
\text { Republic } \\
\text { (CR) } 454\end{array}$ & $\begin{array}{c}\text { Slovak } \\
\text { Republic } \\
\text { (SR) } \\
368\end{array}$ & $\begin{array}{c}\text { Poland (PL) } \\
364\end{array}$ & $\begin{array}{c}\text { Hungary } \\
\text { (HU) } \\
399\end{array}$ & $\begin{array}{c}\text { Z-score/ } \\
\text { p-value } \\
\text { CR/SR } \\
\text { CR/PL } \\
\text { CR/HU } \\
\text { CR/UA }\end{array}$ \\
\hline 1. Strongly agree & 124 & 94 & 75 & 121 & $\begin{array}{c}-0.3162 / \\
0.7489\end{array}$ \\
\hline 2. Agree & 171 & 149 & 143 & 169 & $\begin{array}{l}1.4955 / \\
0.1336\end{array}$ \\
\hline $1+2$ together $\%$, number & $64.98 / 295$ & $66.03 / 243$ & $59.89 / 218$ & $72.68 / 290$ & $\begin{array}{c}-2.4185 / \\
0.0155\end{array}$ \\
\hline 3. Neither agree or disagree & 116 & 93 & 101 & 75 & \\
\hline 4. Disagree & 33 & 27 & 28 & 25 & \\
\hline 5. Strongly disagree & 10 & 5 & 17 & 9 & \\
\hline $\begin{array}{l}\text { Chi-square: } \\
\text { p-value }\end{array}$ & $\begin{array}{c}\text { CR/SR } \\
1.4571 / \\
0.8342\end{array}$ & $\begin{array}{c}\text { CR/PL } \\
8.0185 / \\
0.0909\end{array}$ & $\begin{array}{c}\text { CR/HU } \\
6.4863 / \\
0.1657\end{array}$ & & \\
\hline
\end{tabular}

Table 4. Comparison of STR4 by the nationality of the respondents

\begin{tabular}{|c|c|c|c|c|c|}
\hline $\begin{array}{l}\text { STR4: Our company regularly } \\
\text { monitors, evaluates, and } \\
\text { manages strategic risks. }\end{array}$ & $\begin{array}{l}\text { Czech } \\
\text { Republic } \\
\text { (CR) } 454\end{array}$ & $\begin{array}{l}\text { Slovak } \\
\text { Republic } \\
\text { (SR) } \\
368\end{array}$ & $\begin{array}{c}\text { Poland (PL) } \\
364\end{array}$ & $\begin{array}{l}\text { Hungary } \\
\text { (HU) } \\
399\end{array}$ & $\begin{array}{c}\text { Z-score/ } \\
\text { p-value } \\
\text { CR/SR } \\
\text { CR/PL } \\
\text { CR/HU }\end{array}$ \\
\hline 1. Strongly agree & 72 & 49 & 52 & 61 & $\begin{array}{c}-1.1895 / \\
0.2340\end{array}$ \\
\hline 2. Agree & 141 & 139 & 109 & 160 & $\begin{array}{c}0.7662 / \\
0.4413\end{array}$ \\
\hline $1+2$ together $\%$, number & $46.92 / 213$ & $51.09 / 188$ & $44.23 / 161$ & $55.39 / 221$ & $\begin{array}{c}-2.4696 / \\
0.0135\end{array}$ \\
\hline 3. Neither agree or disagree & 130 & 120 & 124 & 105 & \\
\hline 4. Disagree & 70 & 48 & 51 & 55 & \\
\hline 5. Strongly disagree & 41 & 12 & 28 & 18 & \\
\hline $\begin{array}{l}\text { Chi-square: } \\
\text { p-value }\end{array}$ & $\begin{array}{c}\text { CR/SR } \\
15.9326 / \\
0.0031 \\
\end{array}$ & $\begin{array}{l}\text { CR/PL } \\
3.0308 / \\
0.5527\end{array}$ & $\begin{array}{c}\text { CR/HU } \\
12.0385 / \\
0.0171 \\
\end{array}$ & & \\
\hline
\end{tabular}

Source: Authors 
enterprises. Hungarian entrepreneurs, who showed the highest level of agreement, appear to be most interested in strategic management. In most cases, it was evident that Polish entrepreneurs lag behind in their attitudes towards strategic management of companies. Entrepreneurs in all countries under review agree that strategic management is an important part of company management.

It has been confirmed that the situation in the V4 countries does not differ significantly from other regions. These findings are in line with Clifton et al. (2020). They demonstrated that strategic planning and networking are not implemented adequately. Companies prioritize day-to-day operations, which prevents them to deal with strategic measures. Effective management training is lacking. Similar conclusions were made by Wiesner \& Millett (2012). They concluded that small and medium-sized enterprises have a systematic approach to strategic planning; however, this does not apply to all of them. Our research indicates that an average $77 \%$ of entrepreneurs in SMEs consider strategic management to be an important part of corporate management. On the other hand, companies are not able to use more sophisticated tools within strategic management. Strategic management is very effective there. The findings of the paper are also in line with O'Regan \& Ghobadian (2002), who claim that in small and mediumsized enterprises, the issue of strategic attention is paid little attention to. The authors also agree that the effectiveness of strategic planning has not been addressed sufficiently. This results in a low level of integration of strategic management in dayto-day processes. In the case of Hungarian SMEs, almost $58 \%$ claim they have implemented strategic management in the day-to-day life of the company (the average number for all V4 countries is $54 \%$ ). The results of the research are in line with Tell (2012), who claims that the problem of small and medium-sized enterprises is low interest in strategic management that necessary for the growth of the company, although more than $60 \%$ of the participants in our research perceive the positive effects of strategic management through improving the competitiveness of companies and their stability on markets. All management activities are related to operational activities and administration. Strategic management, however, is separated from day-to-day activities, it is not interconnected with the operation, and management is thus less flexible. At this point, the authors agree with Wang et al. (2007), who claim that strategic planning is sufficiently implemented only in growth-oriented companies, where growth is a priority of owners and managers. Interesting findings are presented by Virglerova et al. (2020) in the context of nonfinancial risks of small and medium-sized enterprises, out of which some might be strategic risks, or by Dvorský et al. (2019), who analysed the business risk of SMEs in the Czech Republic and Slovakia.

In the context of Central Europe, the findings correspond with the results achieved by Egerová et al. (2015), who consider the strategic approach of small and mediumsized enterprises to be insufficient (limited in the context of talent management), where most of them apply ad hoc approach. The analysis and research conducted by Rolínek et al. (2014) indicate the existence of the difference between the implementation of process management and strategic management. While SMEs are able to apply process management, this is not true in the case of strategic management. A similar 
conclusion can be made based on the results of the research by Okręglicka et al. (2015), who analysed the maturity of business processes in SMEs in Poland. In the area of customer-supplier relationships as one of the key elements of process management, the existence of the differences is confirmed by Kot et al. (2018) on the example of SMEs in Poland.

\section{CONCLUSION}

The objective of the paper was to present current theoretical findings in the area of strategic management in the SME sector of V4 countries. Within this objective set, the weight of selected strategic management factors was identified and the trends in the Czech Republic were compared with other V4 countries.

The research results provided interesting trends. On the one hand, SMEs confirmed that strategic management in a company is an important part of corporate management (77.41\% of the respondents); on the other hand, strategic management is not implemented in the everyday life of SMEs and it is not implemented through action plans and programmes. The level of agreement with the statement that quality strategic management improves the competitiveness of companies and their stability on domestic and foreign markets was not very high.

Not surprisingly, SMEs show considerable shortcomings in monitoring and management of strategic risks. Within this research, the average level of agreement with this statement was as low as $49 \%$.

The research results point to the need for increasing the level of strategic risk in the SME segment, which represents a significant factor for improving their competitiveness in the globalizing economic environment.

This research has some limitations. The findings cannot be generalized for any country, since the authors focused only on the V4 countries. The information about the attitudes of owners and managers was obtained by completing an online questionnaire, which means it was impossible to see the reactions of the respondents at a given time and location. On the other hand, the respondents were not influenced by the researchers and the necessity to answer the questions immediately; the advantage was also the anonymity of the respondents. The methods of data collection, verification of reliability and validity of the research, and the response rate exceeding $5 \%$ sufficiently demonstrate the representativeness of the research sample.

\section{References}

Abbass F., \& Alkhafaji (2003). Strategic Management: Formulation, Implementation, and Control in a Dynamic Environment. Psychology Press, New York, USA, pp. 317, ISBN 9780789018106.

Analoui, F., \& Karami, A. (2003). Strategic Management in Small and Medium Enterprises. Thomson Learning, pp. 305, ISBN 9781861529626

Andrews, R., Beynon, M., \& Genc, E. (2017). Strategy Implementation Style and Public Service Effectiveness, Efficiency and Equity. Administrative Sciences, 7(1), 4.

Bacik, R., Fedorko, R., Gavurova, B., Ivankova, V., \& Rigelsky, M. (2020). Differences in financial performance between various categories of hotels in the Visegrad Group countries. Journal of 


\title{
ПЕРЦЕПЦИЈА ОДАБРАНИХ ФАКТОРА СТРАТЕШКОГ УПРАВЉАЊА МСП У В4 ЗЕМЉАМА
}

\author{
Jaroslav Belás, Milan Damborský, Zdenko Metzker, Petr Šuleř
}

\section{Извод}

Циљ рада био је да представи актуелна теоријска сазнања у области стратешког управљања малим и средњим предузећима (МСП) у земљама Вишеградске четворке (B4). У оквиру наведеног циља, квантификована је тежина појединачних фактора стратешког управљања и упоређени су трендови у Чешкој са осталим В4 земљама. Емпиријско истраживање је спроведено између октобра 2019. и марта 2020. у земљама В4 путем онлајн упитника. Укупан број прихваћених упитника био је следећи: Чешка Република (ЧР): 454, Словачка (СР): 368, Пољска (ПЛ): 364 и Мађарска (ХУ): 399. Упитнике су попунили власници компанија и топ менаџери . Емпиријско истраживање је дало неколико занимљивих налаза. С једне стране, МСП су потврдила да је стратешко управљање важан део корпоративног управљања; са друге стране, стратешко управљање се не спроводи у свакодневном животу МСП и не спроводи се кроз акционе планове и програме. Ниво слагања са констатацијом да квалитетно стратешко управљање побољшава конкурентност предузећа и њихову стабилност на домаћем и иностраном тржишту није био на високом нивоу. Није изненађујуће да МСП имају значајне слабости у праћењу и управљању личним ризиком. Резултати истраживања указују на потребу повећања нивоа стратешког управљања ризицима у сегменту МСП, што је важан фактор за унапређење њихове конкурентности у глобализирајућем економском окружењу.

Кључне речи: мала и средња предузећа, стратешки менаџмент, фактори стратешког управљања, земље Вишеградске четворке

International Studies, 13 (2), 279-290.

Belas, J., Amoah, J., Petráková, Z., Kliuchnikava, Y., \& Bilan, Y. (2020). Selected Factors of SMEs Management in the Service Sector. Journal of Tourism and Services, 21 (11), 129-146.

Bodlaj, M., \& Čater, B. (2019). The Impact of Environmental Turbulence on the Perceived Importance of Innovation and Innovativeness in SMEs. Journal of Small Business Management, 57 (2), 417-435.

Carreras, A. B. L., Arroyo, J. C., \& Blanco, J. E. E. (2018). Influence of the strategic planning and the management skills as factors internal of business competitiveness of SME's. Contaduria y
Administracion, 63 (3), 9-10.

Clifton, N., Huggins, R., Pickernell, D., Prokop, D., Smith, D., Thompson, P. (2020). Networking and strategic planning to enhance small and medium-sized enterprises growth in a less competitive economy. Strategic Change, (29), 699-711.

Czerwonka, L., \& Jaworski, J. (2021). Capital structure determinants of small and medium-sized enterprises: evidence from Central and Eastern Europe. Journal of Small Business and Enterprise Development, 28 (2), 277-297.

Dvorský, J., Petráková, Z., \& Polách, J. (2019). Assessing the Market, Financial and Economic Risk Sources By Czech and 
Slovak Smes. International Journal of Entrepreneurial Knowledge, 7 (2), 30-40.

Egerová, D., Lančarič, D., Eger, L., \& Savov, R. (2015). Perspectives of talent management: evidence from Czech and Slovak business organisations. E\&M Economics and Management, 18 (4), 108121.

Ferreira de Araújo Lima, P., Crema, M., \& Verbano, C. (2020). Risk management in SMEs: a systematic literature review and future directions. European Management Journal, 38 (1), 78-94.

Fiala, R., \& Hedija, V. (2015). The Relationship Between Firm Size and Firm Growth: The Case of the Czech Republic. Acta Universitatis Agriculturae et Silviculturae Mendelianae Brunensis, 63 (5), 1639-1644.

Fonseca, L.M., Portela, A.R., Duarte, B., Queirós, J., \& Paiva, L. (2018). Mapping higher education for sustainable development in Portugal. Management \& Marketing. Challenges for the Knowledge Society, 13 (3), 1064-1075.

Frantz, E., Dugan, A., Hinchberger, K., Maseth, B., Al Sharfa, O., \& Al-Jaroodi, J. (2017). SMEs: The effects of strategic management. 2017 IEEE Technology \& Engineering Management Conference (TEMSCON), 388-393.

Fuertes, G., Alfaro, M., Vargas, M., Gutierrez, S., Ternero, R., \& Sabattin, J. (2020). Conceptual Framework for the Strategic Management: A Literature Review -Descriptive. Journal of Engineering.

Gavurova, B., Belas, J., Bilan, Y., \& Horak, J. (2020b). Study of legislative and adminis-trative obstacles to SMEs business in the Czech Republic and Slovakia. Oeconomia Copernicana, 11(4), 689-719.

Gavurova, B., Cepel, M., Belas, J., \& Dvorsky, J. (2020a). Strategic Management in SMEs and Its Significance for Enhancing the Competitiveness in the V4 Countries -A Comparative Analysis. Management \& Marketing. Challenges for the Knowledge Society, 15 (4), 557-569.

Hanggraeni, D., Ślusarczyk, B., Sulung, L. A. K., \& Subroto, A. (2019). The impact of internal, external and enterprise risk management on the performance of micro, small and medium enterprises. Sustainability, 11(7).

Hansen, B., \& R.T. Hamilton (2011). Factors Distinguishing Small Firm Growers and Non-Growers. International Small Business Journal, 29 (3), 278-294.

Hashi, I., \& Krasniqi, B.A. (2011). Entrepreneurship and SME growth: Evidence from advanced and laggard transition economies. International Journal of Entrepreneurial Behavior \& Research, 17 (5), 456-487.

Ivanova, A.S., Holionko, N.G., Tverdushka, T.B., Olejarz, T., \& Yakymchuk, A.Y. (2019). The Strategic Management in Terms of an Enterprise's Technological Development. Journal of Competitiveness, 11(4), 40-56.

Karácsony, P., \& Czibula, A. (2020). Realtionships Between Leadership Style and Organizational Performace in the case of Hungarian Small and Medium-sized Enterprises. Polish Journal of Management Studies, 22 (2), 201-214.

Keřkovský, M., \& Vykypěl, O. (2006). Strategic management: theory for practice. 2nd ed. Praha: C. H. Beck, pp. 206. ISBN 80-7179-453-8. (in Czech)

Kocisova, K., Gavurova, B., \& Behun, M. (2018). The evaluation of stability of Czech and Slovak banks, Oeconomia Copernicana, 9 (2), 205-223.

Kolarov, K., \& Georgieva, S. (2020). Management features in Bulgarian SMES as 
determinats of business internationalization. Knowledge, 9 (1), 81-96.

Journal of Management Studies, 22 (1), 279294.

Kot, S., Goldbach, I.R., \& Ślusarczyk, B. (2018). Supply chain management in SMEs - Polish and Romanian approach. Economics and Sociology, 11 (4), 142-156.

Kudej, M., Gavurova, B., \& Rowland, Z. (2021). Evaluation of the selected economic parameters of Czech companies and their potential for overcoming global crises during the Covid-19 pandemic. Journal of International Studies, 14 (1), 258-275.

Kulej-Dudek, E. (2013). Evaluation of knowledge management in small and medium-sized enterprises, Polish Journal of Management Studies, 2013 (8), 168-174.

Labudová, L., \& Jánošová, D. (2019). Analysis of support and identification of barriers to SMEs in Slovakia and in the Czech Republic. Serbian Journal of Management, 14 (2), 437-453.

Lee, D.H., Choi, S.B., \& Kwak, W.J. (2014). The Effects of Four Dimensions of Strategic Orientation on Firm Innovativeness and Performance in Emerging Market Smalland Medium-Size Enterprises. Emerging Markets Finance \& Trade, 50 (5), 78-96.

Łobos, K., Malátek, V., \& Szewczyk, M. (2020). Management Practices in Area of Human Resources and Monitoring Results as Determinants of SME's Success in Poland and the Czech Republic. E\&M Economics and Management, 23 (2), 114-125.

Metzker, Z., \& Streimikis, J. (2020). CSR activities in the Czech SME segment. International Journal of Entrepreneurial Knowledge, 8 (1), 49-64.

Metzker, Z., \& Zvarikova, K. (2021). The Perception of Company Employees by SMEs with CSR Concept Implementation. International Journal of Entrepreneurial
O'Regan, N., \& Ghobadian, A. (2002). Effective Strategic Planning in Small and Medium Sized Firms. Management Decision, 40 (7), 663-671.

Okręglicka, M., Mynarzová, M., \& Kaňa, R. (2015). Business process maturity in small and medionu-sized enterprises. Polish Journal of Management Studies, 12 (1), 121131.

Pisar, P., \& Bilkova, D. (2019). Controlling as a tool for SME management with an emphasis on innovations in the context of Industry 4.0. Equilibrium. Quarterly Journal of Economics and Economic Policy,14 (4), 763-785.

Rolínek. L, Vrchota, J., Kubecová, J., \& Švárová, M. (2014). The level of process management principles application in SMEs in the selected region on the Czech Republic. Serbian Journal of Management, 9 (2), 203217.

Rosenbusch, N., Brinckman, J., \& Bausch, A. (2011). Is innovation always beneficial? A meta-analysis of the relationship between Innovation and performance in SMEs. Journal of Business Venturing, 26 (4), 441-457.

Saltaji, I. M. (2013). Corporate governance relationship with strategic management. Internal Auditing and Risk Management, 2 (30), 277-284.

Sedláčková, H., \& Buchta, K. (2006). Strategic analysis. Praha: C. H. Beck, pp. 121. ISBN 8071793671. (in Czech)

Short, J.C., Ketchen, D.J., Plamer, \& Hult, G.T.M. (2007). Firm, Strategic Group, and Industry Influences on Performance. Strategic Management Journal, 28 (2), 147167.

Srovnalíková, P., Semionovaite, E., Baranskaitè, E., \& Labanauskaitè, D. (2020). Evaluation of the Impact of Sharing 
Economy on Hotel Business. Journal of Tourism and Services, 20 (11), 150-169.

Szczepańska-Woszczyna, K. (2018). Strategy, Corporate Culture, Structure and Operational Processes as the Context for the Innovativeness of an Organization. Foundations of Management, 10 (1), 33-44.

Švárová, M., \& Vrchota, J. (2013). Strategic management in micro, small and medium-sized businesses in relation to financial success of the enterprise. Acta Universitatis Agriculturae et Silviculturae Mendelianae Brunensis, 7, 2859-2866.

Tell, J. (2012). Managerial strategies in small, fast-growing manufacturing firms. Journal of Management Development, 31 (7), 700-710.

Tichá, I., \& Hron, J. (2005). Strategic management. 1st ed. Praha: ČZÚ. ISBN 80213-0922-9. (in Czech)

Tkacova, A., Gavurova, B., Danko, J., \& Cepel, M. (2017). The importance of evaluation of economic determinants in public procurement processes in Slovakia in 2010-2016. Oeconomia Copernicana, 8 (3), $\square$ 367-382.

Virglerova, Z., Dvorsky, J., Kozubikova, L., \& Cepel, M. (2020). Perception of nonfinancial risk determinants in SMEs in Visegrad countries. Oeconomia Copernicana, 11 (3), 509-529.

Wang, C., Walker, E., \& Redmond. J. (2007). Explaining the Lack of Strategic Planning in SMEs: The Importance of Owner Motivation. International Journal of Organizational Behavior, 12 (1), 1-16.

Wiesner, R., \& Millett, B. (2012): Strategic approaches in Australian SMEs: Deliberate or emergent? Journal of Management \& Organization, 18 (1). 98-122. 